\title{
Lethal toxicity of Vibrio harveyi to cultivated Penaeus monodon induced by a bacteriophage
}

\author{
Lila Ruangpan ${ }^{1}$, Yaowanit Danayadol ${ }^{1}$, Sataporn Direkbusarakom ${ }^{1}$, \\ Siriporn Siurairatana ${ }^{2}$, T. W. Flegel ${ }^{2, *}$
}

${ }^{1}$ National Institute of Coastal Aquaculture, Songkhla 90000, Thailand

${ }^{2}$ Dept Pathology, Faculty of Medicine, Rama Thibodi Hospital, and Dept Biotechnology, Faculty of Science, Mahidol University, Rama 6 Road, Bangkok 10400, Thailand

\begin{abstract}
In Southern Thailand in 1996, intense luminescence in many shrimp rearing ponds was accompanied by massive mortality resulting in total crop loss within 3 or $4 \mathrm{~d}$. Mortality was correlated with gross signs which shrimp farmers called (English translation) tea-brown gill syndrome (TBGS). Histological examination of moribund shrimp revealed massive lesions of the hepatopancreas characterized by hemocytic infiltration and the presence of bacterial cells. Bacterial isolation yielded several strains tentatively identified as Vibrio harveyi on the basis of luminescence and growth on BTB Teepol agar. Representative isolate VH1039 was selected and identified by biochemical tests as $\mathrm{V}$. harveyi. When strain VH1039 and the other luminescent isolates were injected into normal shrimp $\left(1 \times 10^{7}\right.$ cells shrim $\mathrm{p}^{-1}$ ), no significant mortality was observed in comparison with control shrimp injected without bacteria. Nor was any significant mortality observed after injection of supernatant fluids from normal or sonicated bacterial cultures of VH1039 $\left(1 \times 10^{8}\right.$ cells $\left.\mathrm{ml}^{-1}\right)$. Transmission electron microscopy (TEM) of hepatopancreatic tissue from farmed TBGS shrimp revealed bacterial cells of Vibrio morphology together with large numbers of bacteriophage particles that had round to hexagonal heads of approximately $60 \mathrm{~nm}$ diameter and tails of approximately $100 \mathrm{~nm}$ length. These were either free, attached to cell walls of intact bacteria or in various stages of replication within bacterial cells. Gills of farmed TBGS shrimp were subsequently homogenized in lobster haemolymph buffer (LHB) and membrane filtered $(0.22 \mathrm{\mu m})$. Compared to control shrimp injected with LHB, shrimp injected with the $1000 \times$ diluted gill filtrate (DGF) showed no significant mortality. However, when DGF was injected together with $1 \times$ $10^{7}$ cells of strain VH1039, there was total mortality within $48 \mathrm{~h}$. High and rapid mortality concurrent with brown gills was seen only in the mixed injection group. TEM of the artificially infected shrimp tissues did show the presence of bacterial cells, but no mature bacteriophage particles or lysed bacterial cells were found similar to those seen in farmed TBGS shrimp. In further tests, addition of DGF to cultures of VH1039 induced extreme but transitory toxicity of culture filtrates from 24 to 36 h. Treatment of DGF with a germicidal lamp (UV) for $30 \mathrm{~min}$ or with heat at $100^{\circ} \mathrm{C}$ for $15 \mathrm{~min}$ failed to stop shrimp mortality from mixed DGF/VH1039 injections. However, mortality was stopped if the heated DGF was treated with DNase. The results suggested that a bacteriophage may sometimes mediate the toxicity of $V$. harveyi in Penaeus monodon by the transfer of a toxin gene(s) or a gene, $s$ ) controlling toxin production.
\end{abstract}

KEY WORDS: Vibrio harveyi Penaeus monodon $\cdot$ Bacteriophage $\cdot$ Induced toxicity

\section{INTRODUCTION}

In Southern Thailand from April to August 1996 numerous shrimp farmers reported the occurrence of unusually intense luminescence in their rearing ponds

-Addressee for correspondence. E-mail: sctwf@mahidol.ac.th for the black tiger prawn Penaeus monodon. A survey of rearing water from these ponds showed that large numbers of luminescent bacteria were present (Ruangpan et al. 1997). In some but not all, massive mortality occurred within 3 to $4 \mathrm{~d}$ after the first appearance of moribund shrimp exhibiting tea-brown gills. Farmers judged that this browning and its associated high mortality differed from browning that results from poor 
water quality or low dissolved oxygen (Chanratchakool et al. 1995), and they named it 'nguak see cha' in Thai, which translates to 'tea-brown gill syndrome' (TBGS) in English.

Routine histological investigation (Lightner 1996) of TBGS shrimp revealed the presence of massive hepatopancreatic necrosis apparently caused by the large numbers of bacterial cells also seen in the sections. However, isolation of several bacterial strains and re-injection into normal shrimp gave no mortality, indicating a cause of more complex etiology. This report describes more detailed studies, including examination by transmission electron microscopy (TEM) which indicated that a bacteriophage may be implicated in the high mortality of TBGS shrimp.

\section{MATERIALS AND METHODS}

Normal shrimp and those with TBGS syndrome were obtained from farms in Songkhla Province, Southern Thailand. They ranged in size from 11 to $15 \mathrm{~cm}$. Moribund TBGS specimens were used for preparation of gill homogenates as described below. Normal shrimp for experimental infection and controls were brought to the laboratory of the National Institute for Coastal Aquaculture (NICA) and acclimatized in $500 \mathrm{l}$ aquaria containing 200 shrimp each. The aquaria contained filtered sea water at ambient salinity ( 25 to $28 \mathrm{ppt}$ ). For injection trials and controls, tests were carried out in duplicate in 100 l aquaria with 7 shrimp in each aquarium.

Preparation of specimens for histological examination by H\&E staining and fixation of TEM specimens in phosphate buffered glutaraldehyde were done as described by Lightner (1996). Further TEM processing was according to Fegan et al. (1991) and examination was carried out using a Hitachi HU-12 electron microscope.

From TBGS shrimp, bacteria were isolated from the hepatopancreas (HP) by streaking from aseptically removed hepatopancreatic tissue on bromthymol blue teepol (BTB teepol) agar (Difco) or triptic soy agar (TSA) (Difco) containing a total of $2 \% \mathrm{NaCl}$. For haemolymph, $0.1 \mathrm{ml}$ of aseptically removed haemolymph from the ventral sinus was spread on the same media. Plates were incubated in a $35^{\circ} \mathrm{C}$ incubator and individual colonies were restreaked on TSA to obtain pure cultures. These were examined for luminescence within $24 \mathrm{~h}$ after transfer to fresh TSA plates. Isolates were stored on TSA containing $2 \% \mathrm{NaCl}$ at room temperature $\left(28\right.$ to $\left.35^{\circ} \mathrm{C}\right)$. One luminescent colony that grew on BTB teepol agar (isolate 1039 from shrimp hepatopancreatic tissue) was identified as Vibrio harveyi based on standard biochemical tests and assimila- tion of carbon compounds (Sneath et al. 1986). It was designated $\mathrm{VH} 1039$. A standard curve was based on colony forming units (cfu) determined by standard plate counts versus optical density at $540 \mathrm{~nm}$. For injection trials, VH1039 was grown in tryptic soy broth (TSB) (Difco) containing $2 \% \mathrm{NaCl}$ for $24 \mathrm{~h}$ (i.e. exponential growth phase) and diluted in sterile artificial sea water (ASW) to $1 \times 10^{8} \mathrm{cfu} \mathrm{m}^{-1}$ before intramuscular injection $(0.1 \mathrm{ml})$ into the sixth abdominal segment of normal shrimp. Control shrimp were injected with carrier solution only. Survival was monitored for $120 \mathrm{~h}$ post injection.

Gill homogenates were prepared in lobster haemolymph buffer (LHB) (Patterson \& Stewart 1974, Boonyaratpalin et al. 1993) by using gill tissue at approximately equal volume to the buffer. These homogenates were centrifuged at low speed before the supernatant fluid was separated into 2 fractions. A minor fraction was removed and stored at $4^{\circ} \mathrm{C}$ as untreated gill homogenate (UGH). The majority was membrane filtered using sterile Millipore nitrocellulose filters $(0.22 \mu \mathrm{m})$. The filtrates were first confirmed to be free of bacteria by plating on TSA and then diluted $1000 \times$ before preservation at $4^{\circ} \mathrm{C}$ as diluted gill filtrate (DGF). For injection into test shrimp $(0.1 \mathrm{ml}$ into the ventral sinus at the first abdominal segment), UGH and DGF were either used directly or further diluted in LHB before being mixed $(1: 1)$ with LHB or with a suspension of VH1039 $\left(1 \times 10^{8} \mathrm{cfu} \mathrm{ml}^{-1}\right.$ or dilutions of same). Additional tests involved treatment of DGF by exposure to a germicidal lamp at $10 \mathrm{~cm}$ for $30 \mathrm{~min}$, by heating at $100^{\circ} \mathrm{C}$ for $10 \mathrm{~min}$ or by heating at $100^{\circ} \mathrm{C}$ for $10 \mathrm{~min}$ followed by treatment with DNase (100 units of DNase I, BDL Corp.) for $10 \mathrm{~min}$ at room temperature before mixing with bacteria prior to injection. After injection the shrimp were monitored for $96 \mathrm{~h}$ and morbidity, mortality and survival were recorded. Where possible, moribund shrimp were removed just before death so that gill and hepatopancreatic tissues could be obtained for normal histology and TEM.

For bacterial toxin tests, DGF $(1 \mathrm{ml})$ was added to $50 \mathrm{ml}$ TSB inoculated with $5 \mathrm{ml}$ of an exponential phase culture (18 h) of VH1039 also grown in TSB. For control cultures, no DGF was added. Numbers of bacterial cells in these cultures were estimated at $6 \mathrm{~h}$ intervals as described above. Aliquots of $1 \mathrm{ml}$ were removed from these bacterial cultures at $12 \mathrm{~h}$ intervals and diluted to the equivalent of $1 \times 10^{8} \mathrm{cfu} \mathrm{m}^{-1}$ with sterile LHB before centrifugation, membrane filtration $(0.22 \mu \mathrm{m})$ and storage at $-20^{\circ} \mathrm{C}$. To determine toxicity, these filtrates $(0.1 \mathrm{ml})$ were injected into normal shrimp and the resulting mortality was compared to the mortality of control shrimp injected with an equal amount of LHB. 


\section{RESULTS}

\section{Histology of naturally infected TBGS shrimp}

Except for slight haemocytic aggregation (Fig. 1a) in the interstitial spaces of the HP, many TBGS shrimp from rearing ponds showed no clearly visible pathology, even in the gills. We postulated that such specimens were in the early stages of infection. Other specimens showed more obvious haemocytic aggregation in the HP (Fig. 1b) and the anterior midgut caecum (Fig. 1c), but still showed no microscopically visible pathology in the gills (Fig. 1d). We postulated that these specimens were at an intermediate stage of infection. At these postulated early and intermediate stages of infection, the tubule epithelial cells appeared to be relatively unaffected by the bacterial invasion. Other brown-gilled specimens showed massive haemocytic aggregation in the HP accompanied by bacterial invasion of the tubule epithelia, necrosis of adjacent tubules, encapsulation and melanization (Fig. 1e). In these specimens, a state of
Fig. 1 Penaeus monodon. Histopathology associated with TBGS. (a) Early stages of TBGS showing 1 of the foci of light haemocytic infiltration of the interstitial spaces of the hepatopancreas (HP) (scale bar $=40 \mu \mathrm{m})$. Some bacteria are evident (arrows). (b, c) A later stage of infection with moderate but generalized haemocytic infiltration in the HP (b) and the anterior midgut caecum $(\mathrm{c})$ (scale bar $=100 \mu \mathrm{m}$ ). Note that the HP tubule epithelium is still free of bacteria. (d) Photomicrograph from the same animal as in $(b, c)$ showing normal gill histology, even though the gills were grossly discolored brown in the field specimen (scale bar $=40 \mu \mathrm{m}$ ). (e) Photomicrograph of HP tissue from very advanced stages of TBGS infection showing invasion of tubule epithelia, encapsulation of bacterial cells and melanization (scale bar $=40 \mu \mathrm{m}$ ). This was accompanied by general septacaemia. (f) Photomicrograph of gill tissue from the same specimen as in (e) showing bacteria in enlarged phagocytic cells (straight arrows) and in the haemolymph (curved arrows) and visible melanization (scale bar $=10 \mu \mathrm{m}$ )

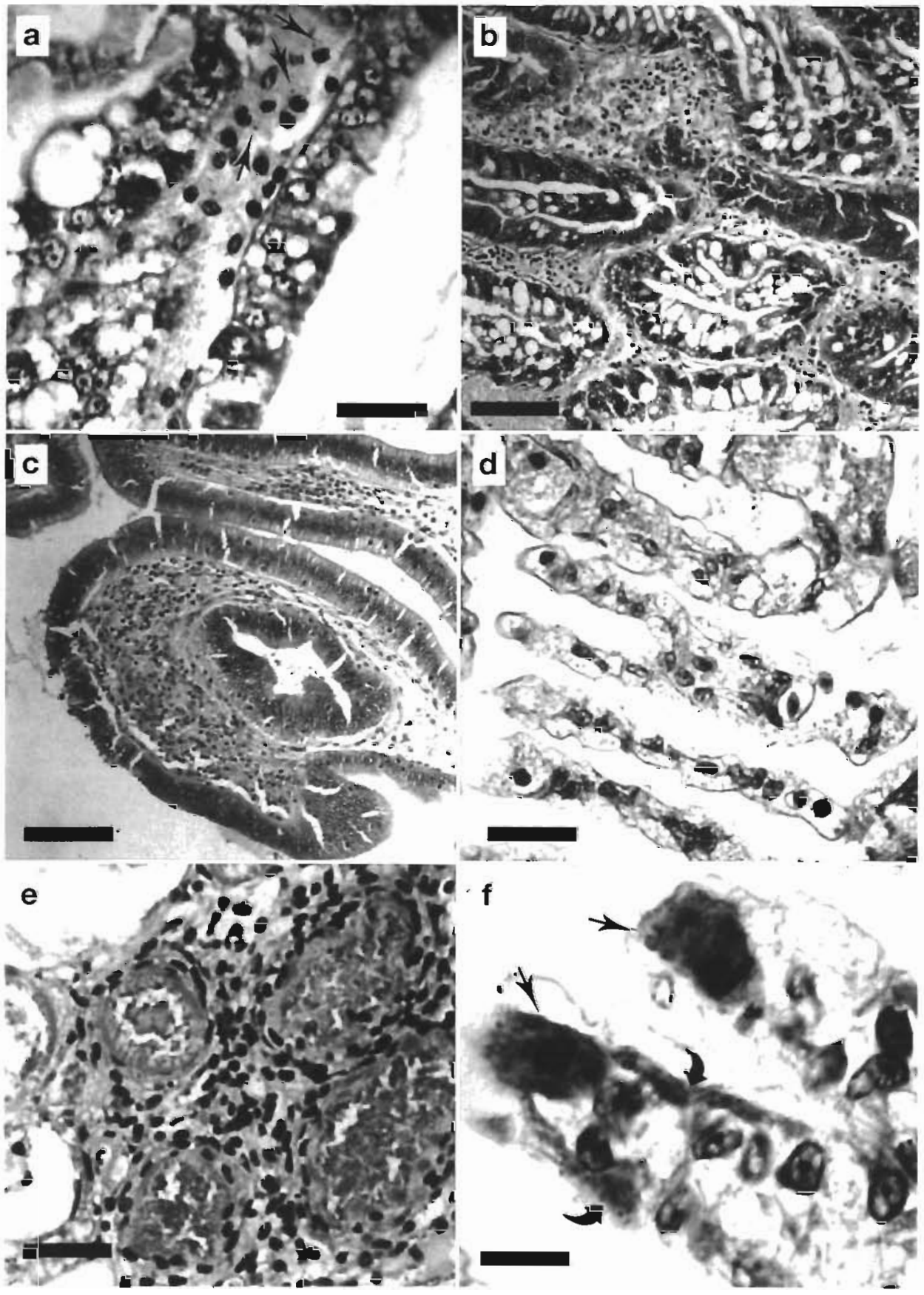


general bacterial septicaemia was evident with large numbers of bacterial cells in the haemolymph, and melanized bacterial lesions were clearly visible microscopically in the gills (Fig. 1f). We postulated that these specimens were at an advanced stage of infection.

Examination of hepatopancreatic interstitial tissues with the electron microscope revealed the presence of free and engulfed bacteria, as expected, but also large numbers of viral particles replicating in the bacterial cytoplasm, free in tissue fluids or attached to bacterial cell walls (Fig. $2 \mathrm{a}-\mathrm{c}$ ). The viral particles possessed a round to hexagonal head (60 nm diameter) and a tail $(100 \times 10 \mathrm{~nm})$ and morphologically resembled bacteriophage particles of lambda phage or $\mathrm{T}_{4}$ phage (Stryer 1988).

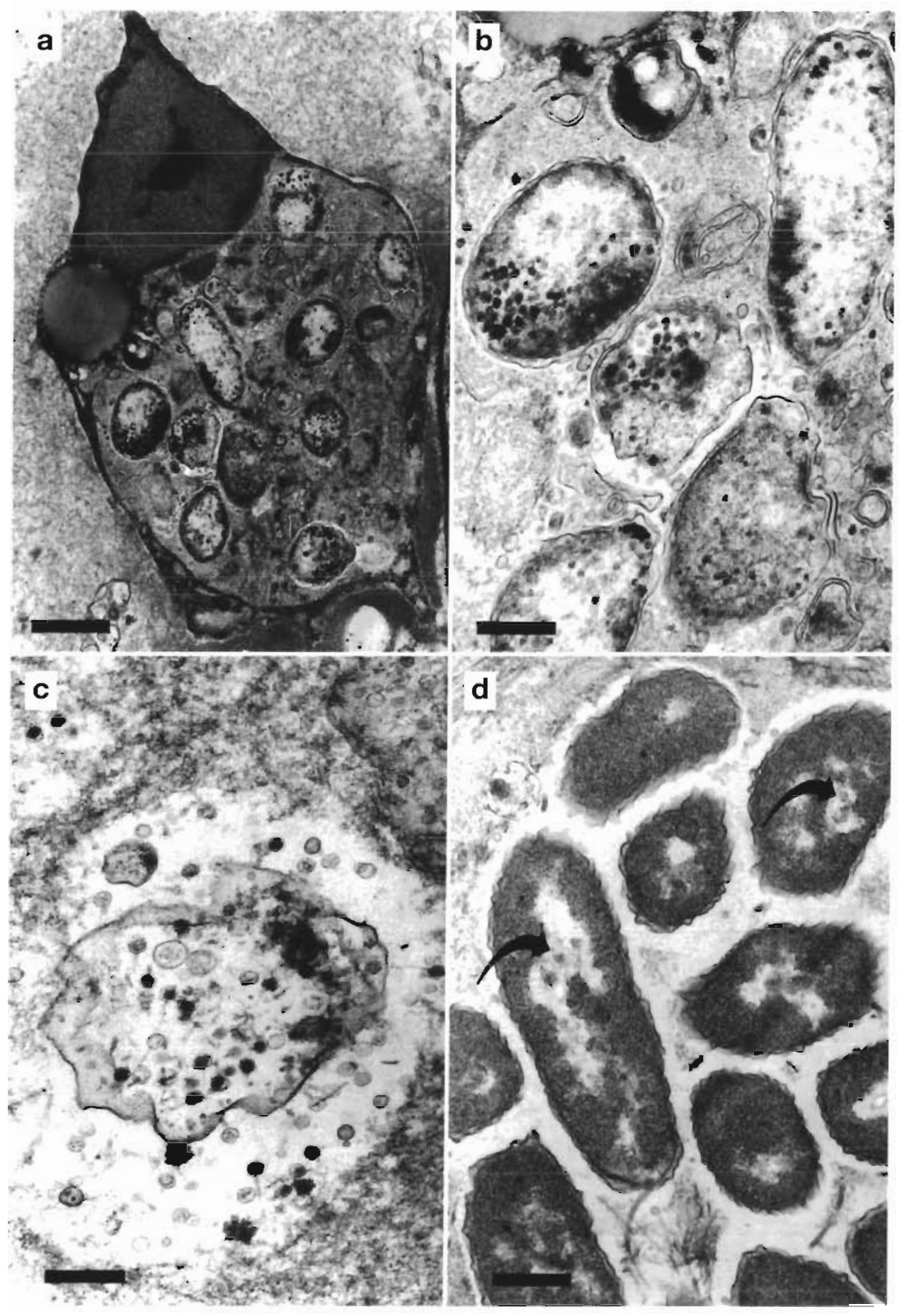

Fig. 2. Penaeus monodon. Transmission electron micrographs of tissues from field infected and experimentally infected shrimp exhibiting TBGS. (a) Low magnification of a phagocytic cell from interstitial fluid of hepatopancreatic tissue showing engulfed bacteria containing developing phage particles (scale bar $=1.2 \mu \mathrm{m}$ ). (b) High magnification of bacteria in the phagocytic cell shown in. (a) (scale bar $=400 \mathrm{~nm}$ ). (c) A lysed bacterial cell in interstitial tissues of the hepatopancreas showing mature bacteriophage particles with round to hexagonal heads $(60 \mathrm{~nm})$ and filamentous tails $(100 \times 10 \mathrm{~nm})$ (scale bar $=300 \mathrm{~nm}$ ). (d) Free bacterial cells in the interstitial fluid of the hepatopancreas from shrimp experimentally injected with a mixture of VH1039 and DGF and showing TBGS. Two of these bacteria contain what may be developing phage particles (arrows) (scale bar $=400 \mathrm{~nm}$ \} 


\section{Injection trials with bacterial isolates}

When bacterial isolates derived from pond-reared TBGS shrimp were injected into laboratory shrimp at $1 \times 10^{5} \mathrm{cfu}$ shrimp $^{-1}$ (i.e. $0.1 \mathrm{ml}$ of a solution of $1 \times$ $10^{6} \mathrm{cfu} \mathrm{ml}^{-1}$ ), observed mortality was not different from the LHB-injected controls and not more than 1 in every 14 injected shrimp. However, for some strains of Vibrio harveyi, low mortality of up to 5 shrimp out of 14 was observed within $12 \mathrm{~h}$ post injection of $1 \times 10^{7} \mathrm{cfu}$ shrimp ${ }^{-1}$ (i.e. $0.1 \mathrm{ml}$ of a solution of $1 \times 10^{8} \mathrm{cfu} \mathrm{ml}^{-1}$ ). Similar low mortality was observed within $12 \mathrm{~h}$ post injection of $0.1 \mathrm{ml}$ of supernatant fluids from untreated or sonicated suspensions of $1 \times 10^{8} \mathrm{cfu} \mathrm{m}^{-1}$. Since there was no further mortality thereafter, it was concluded that the initial mortality resulted from a bacterial toxin that could be made innocuous with sufficient dilution (e.g. to $1 \times 10^{6} \mathrm{cfu} \mathrm{ml}^{-1}$ ).

\section{Injection of gill homogenates}

The results from injection of gill extracts from TBGS shrimp are shown in flow chart form in Fig. 3. Injection of UGH (diluted 1:1000) gave 90\% mortality within $48 \mathrm{~h}$, but no significant mortality ( 7 and $14 \%$, respectively) resulted with injection of DGF or VH1039 at $1 \times$ $10^{7}$ cfu shrimp ${ }^{-1}$. In contrast, high mortality was obtained when DGF was mixed with VH1039 (100\%).
The mortality obtained decreased with increasing dilution of DGF used in the mixtures. Re-filtration of the DGF/VH1039 mixtures removed their ability to kill the shrimp. This indicated that some factor in the gill filtrates combined with the bacteria to cause high mortality. Repeat trials using membrane-filtered gill filtrates from the experimentally infected shrimp gave similar results.

Results from tests with treated membrane filtrates are shown in Fig. 4. Treatment with a germicidal lamp $(10 \mathrm{~cm}$ for $30 \mathrm{~min})$ and heating at $100^{\circ} \mathrm{C}$ did not remove the ability of DGF to kill shrimp when combined with VH1039. However, treating the heated filtrate with DNase did neutralize the killing activity. Results from these tests suggested that DNA was necessary for the bacterial interaction that caused mortality.

Moribund shrimp from the UGH and combined DGF/ bacterial injection groups showed gross signs of brown gills, similar to TBGS shrimp seen in the field when using homogenates from either field infected or laboratory infected shrimp. However, examination of these shrimp by normal histology with the light microscope revealed no obvious signs of bacterial infection in the hepatopancreas or elsewhere. However, examination of hepatopancreatic tissues by TEM (Fig. 2d) did reveal the presence of bacterial cells, possibly containing incomplete bacteriophage particles. No bacterial cell lysis and no complete bacteriophage particles were seen.

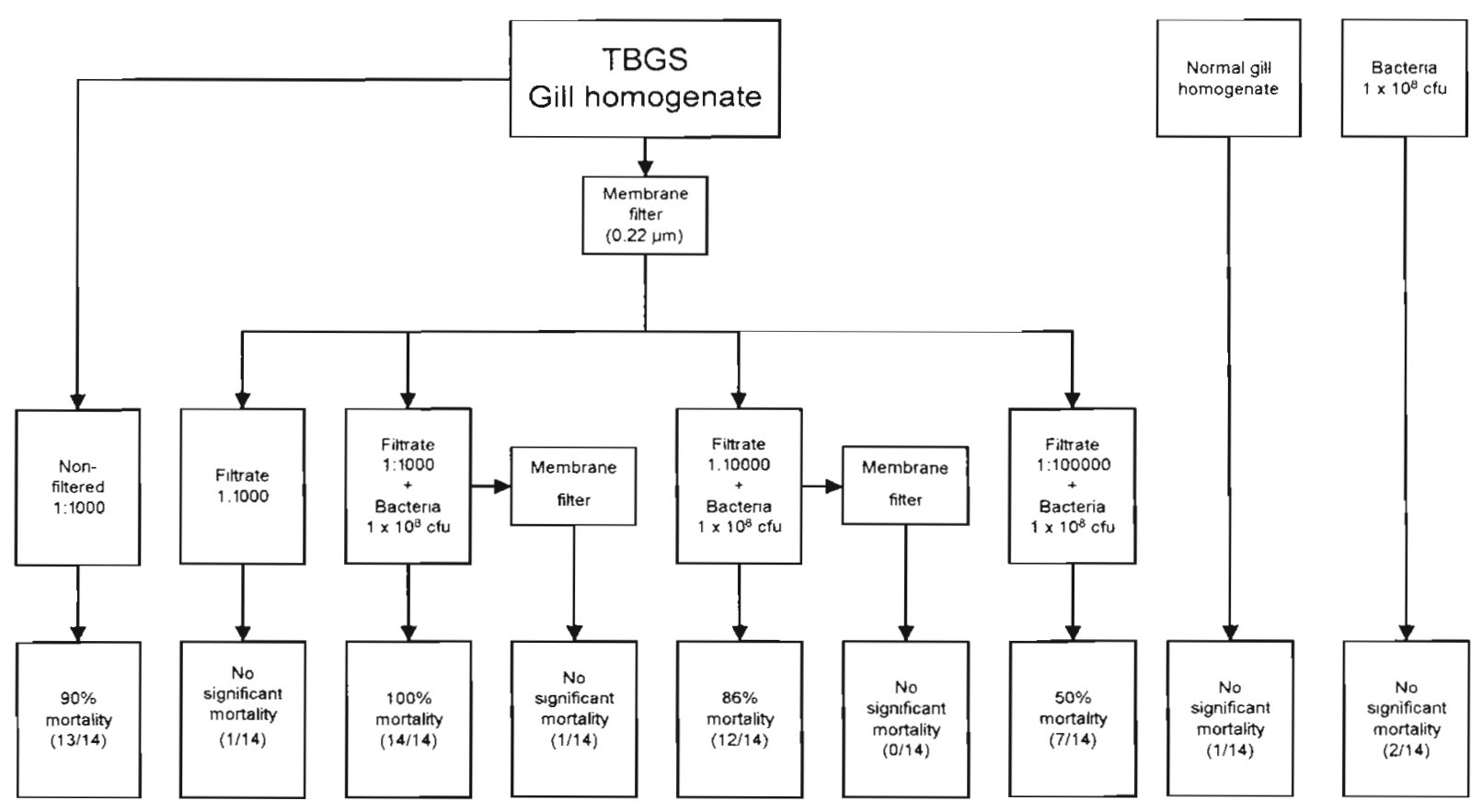

Fig. 3. Experimental protocol and results from tests to determine whether the bacteriophage particles seen in electron micrographs of TBGS shrimp tissue were implicated in shrimp mortality. Significant mortality occurred only with non-filtered gill homogenates and with mixtures of bacteria in filtered gill homogenate 


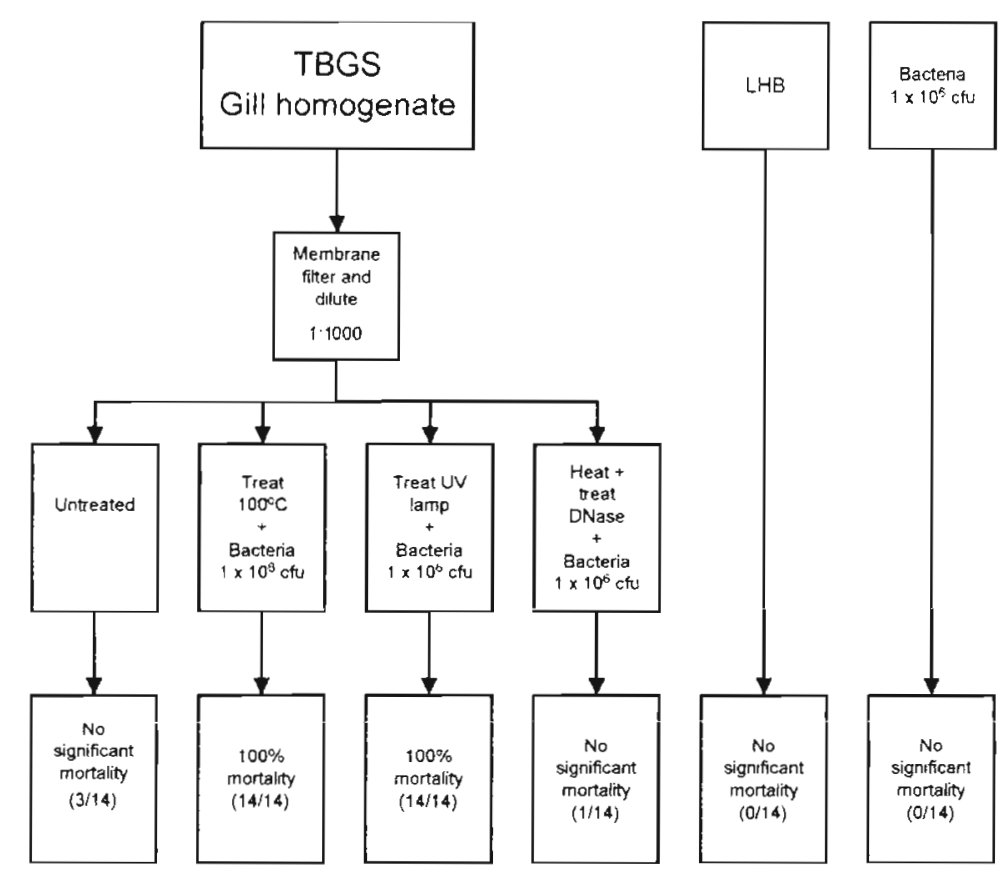

Fig. 4. Experimental protocol and results from tests to determine the effect of various DGF treatments on the ability of DGF to cause shrimp mortality when combined with bacterial cells before injection. UV treatment or heat treatment alone $\left(100^{\circ} \mathrm{C}\right.$ for $\left.15 \mathrm{~min}\right)$ did not decrease shrimp mortality, but heat treatment followed by DNase treatment did

\section{Bacterial toxin tests}

When DGF was mixed with growing cultures of VH1039 in preliminary tests, culture filtrates at 12 and $24 \mathrm{~h}$ gave high mortality (i.e. they were highly toxic to shrimp during exponential growth). By contrast, filtrates from similar cultures without added DGF gave low mortality (Table 1). The toxicity in these culture filtrates was destroyed by heating to $100^{\circ} \mathrm{C}$ for $10 \mathrm{~min}$ and it disappeared with Ionger cultivation times.

Table 1. Penaeus monodon. Percent shrimp mortality resulting from preliminary trials on injection of filtrates from sonicated bacterial cultures and bacterial cultures treated or not treated with DGF

\begin{tabular}{|lc|}
\hline Injection group & $\%$ mortality \\
\hline LHB control & 0 \\
Culture supernatant $\left(1 \times 10^{6}\right)$ & 0 \\
Culture supernatant $\left(1 \times 10^{8}\right)$ & 21 \\
Sonicated culture $\left(1 \times 10^{8}\right)$ & 21 \\
Culture with DGF $(12 \mathrm{~h})$ & 50 \\
Culture with DGF $(24 \mathrm{~h})$ & 78 \\
Culture with DGF $(36 \mathrm{~h})$ & 17 \\
Culture with DGF $(48 \mathrm{~h})$ & 13 \\
Culture with DGF $(24 \mathrm{~h})$ boiled & 0 \\
\hline
\end{tabular}

\section{DISCUSSION}

The results reported here indicate that toxicity of VH1039 to Penaeus monodon was mediated by a bacteriophage. The mechanism of the mediation probably did not involve the simple release of pre-existing toxins as a result of bacterial lysis, since supernatant fluids from sonicated and nonsonicated broth containing VH1039 had low and equal toxicity only at a concentration of $1 \times 10^{8} \mathrm{cfu} \mathrm{m} \mathrm{m}^{-1}$ and this toxicity was lost upon dilution to the equivalent of $1 \times 10^{6} \mathrm{cfu}$ $\mathrm{ml}^{-1}$. Filtrates from cultures of $\mathrm{VH} 1039$ grown in the presence of DGF became highly toxic during the exponential phase of growth (12 and $24 \mathrm{~h}$ ). It is not clear from the experimental results whether the toxicity mediated by the bacteriophage was different from that in normal culture filtrates of VH1039 which caused low shrimp mortality. If toxin production is phage mediated, there are 2 possibilities. The phage either promotes the production of an existing toxin or somehow induces the production of a new one. If the toxin is a new one, then it could arise either from the induction of a previously silent bacterial gene or from a newly introduced gene carried by the phage itself. The latter phenomenon has been reported for toxic strains of Escherichia coli (Smith et al. 1983), Staphylococcus (Betley \& Mekalanos 1985) and Vibrio cholerae (Levin \& Tauxe 1996, Waldor \& Mekalanos 1996). In the case of these human pathogens, the phages are known to carry copies of toxin genes and to transduce non-toxic host bacteria into toxin-producing strains.

The possibility that gene transfer is involved in the work reported here is supported by the results in which heat-treated and UV-treated DGF showed that fully active virions were probably not required to obtain high mortality, although it is possible that the phage may be extremely stable in UV light and heat. On the other hand, DNase treatment of heated DGF did prevent mortality, and it is unlikely that the enzyme would be able to degrade DNA of intact virions. Thus, the weight of the evidence suggests that the nature of the DGF-bacterial interaction involved the transfer of genetic material. However, it is not possible from the results to suggest whether the phage carried the toxin gene itself or another gene which induced an endogenous bacterial toxin gene. Further work is required to distinguish between these 2 possibilities.

Whatever the mechanism, the involvement of a bacteriophage in the toxicity of Vibrio species to cultivated shrimp may be a significant problem for shrimp farm- 
ers. It may explain, at least partially, the confusion that prevails about variation in toxicity of bacterial strains isolated from diseased shrimp and from shrimp ponds, and it supports the contention of Pizzutto \& Hirst (1995) that virulence in $V$. harveyi is derived from mobile genetic elements. It may also explain why many strains quickly lose their virulence to shrimp when serially subcultured in the laboratory. Although isolate VH1039 was derived from TBGS shrimp, we now believe that it was separated from its viral partner upon single colony selection during the process of pure culture preparation. This may happen frequently during the isolation, purification and transfer of cultures in the laboratory. In the future, it may be worthwhile observing primary bacterial isolation plates from moribund farmed shrimp for any indications that a bacteriophage(s) partner is present.

Knowledge of this mechanism for induced toxicity also has implications for the management and control of shrimp pathogens. It is especially significant that the ability of the gill filtrates to interact with the bacterium was not removed by UV or heat treatment. It is a common practice for shrimp feed manufacturers to use shrimp head meal as a component in their feed. The results presented here indicate that this may be a dangerous practice in some circumstances. There are also anecdotal reports from Thailand that some farmers are currently preparing a crude vaccine from moribund shrimp infected with white-spot syndrome virus (WSSV) by heat treatment of tissue homogenates at $80^{\circ} \mathrm{C}$ for 30 min. They then mix this with shrimp feed and administer it to shrimp at 5 d intervals. Our results indicate that some caution may be in order.

The biochemical nature of the toxin is unknown, but its heat lability suggests that it may be proteinaceous, like cholera toxin (Waldor \& Mekalanos 1996). If it is toxic to shrimp by bath exposure (not tested here), then shrimp farmers might risk losses whenever there are large numbers of Vibrio harveyi in their pond water.

The size and morphology of the bacteriophage described here is similar to that of lambda phage, $T_{4}$ phage and $\mu$ phage (Douglas 1975, Birge 1988), all of which are DNA viruses. The phage which causes toxin transduction on Escherichia coli is a DNA coliphage (Douglas 1975), while that which causes toxin transfer in Vibrio cholerae (CTX $\varnothing$ ) is a filamentous DNA phage (Levin \& Tauxe 1996, Waldor \& Mekalanos 1996). These examples indicate that the phenomenon of virally induced bacterial toxicity is not uncommon and may be mediated by very different viral groups (Cheetham \& Katz 1995). It may be a more important factor in bacterial diseases of aquatic animals than hitherto suspected. With respect to shrimp, the major bacterial pathogens are Vibrio species, most notably $V$. harveyi, V. parahaemolyticus, and $V$. vulnificus. Studies are needed to determine whether the phage described here has species and/or strain specificity with $V$. harveyi and whether similar viruses exist for the other Vibrio pathogens of shrimp

Acknowledgement. The authors would like to thank the National Center for Genetic Engineering and Biotechnology, Thailand, for support in carrying out this work.

\section{LITERATURE CITED}

Betley MJ, Mekalanos JJ (1985) Staphylococcal enterotoxin A is encoded by phage. Science 229:185-187

Birge EA (1988) Bacterial and bacteriophage genetics, 2nd edn. Springer Verlag, New York

Boonyaratpalin S, Supamataya K, Kasornchandra J, Direkbusarakom S, Aekpanithanpong U, Chantanachookhin C (1993) Non-occluded baculo-like virus, the causative agent of yellow-head disease in the black tiger shrimp Penaeus monodon. Fish Pathol 28:103-109

Chanratchakool P, Turnbull JF, Funge-Smith S, Limsuwan C (1995) Health management in shrimp ponds, 2nd edn. Aquatic Animal Health Research Institute, Kasetsart University, Bangkok, p 76, p 84-87

Cheetham BF, Katz ME (1995) A role for bacteriophages in the evolution and transfer of bacterial virulence determinants. Mol Microbiol 18:201-208

Douglas J (1975) Bacteriophages, 1st edn. T\&A Constable Ltd, Edinburgh

Fegan DF, Flegel TW, Sriurairatana S, Waiakrutra M (1991) The occurrence, development and histopathology of monodon baculovirus in Penaeus monodon in Southern Thailand. Aquaculture 96:205-217

Levin BR, Tauxe RV (1996) Cholera: nice bacteria and bad viruses. Curr Microbiol 6:1389-1391

Lightner DV (ed) (1996) A handbook of pathology and diagnostic procedures for diseases of penaeid shrimp. World Aquaculture Soc, Baton Rouge, LA

Patterson WD, Stewart JE (1974) In vitro phagocytosis by hemocytes of the American lobster Homarus americanus. J Fish Res Board Can 31:1051-1056

Pizzutto M, Hirst RG (1995) Classification of isolates of Vibrio harveyi virulent to Penaeus monodon larvae by protein profile analysis and M13 DNA fingerprinting. Dis Aquat Org 21:61-68

Ruangpan L, Sodthongkong C, Srikaew Y (1997) Luminous bacteria in the Penaeus monodon aquacultural area of Songkhla and their sensitivities to some antibiotics. Technical Paper No. 18/1997, National Institute of Coastal Aquaculture, Dept Fisheries, Songkhla (in Thai with English abstract)

Smith HW, Green P, Parsell Z (1983) Vero cell toxins in Escherichia coli and related bacteria: transfer by phage and conjugation and toxic action in laboratory animals, chickens and pigs. J Gen Microbiol 129:3121-3127

Sneath PHA, Mair NS, Sharpe ME, Holt JG (1986) Bergey's manual of systematic bacteriology. Williams and Wilkens, Baltimore

Stryer L (1988) Biochemistry, 3rd edn. WH Freeman and Co, New York

Waldor MK, Mekalanos JJ (1996) Lysogenic conversion by a filamentous phage encoding cholera toxin. Science 272 : 1910-1914 